\title{
A Comparison of Producer Gas, Biochar, and Activated Carbon from Two Distributed Scale Thermochemical Conversion Systems Used to Process Forest Biomass
}

\author{
Nathaniel Anderson ${ }^{1, *}$, J. Greg Jones ${ }^{1}$, Deborah Page-Dumroese ${ }^{2}$, Daniel McCollum ${ }^{3}$, \\ Stephen Baker ${ }^{4}$, Daniel Loeffler ${ }^{5}$ and Woodam Chung ${ }^{5}$
}

1 Rocky Mountain Research Station, USDA Forest Service, 200 East Broadway, Missoula, MT 59807, USA; E-Mail: jgjones@fs.fed.us

2 Rocky Mountain Research Station, USDA Forest Service, Moscow, ID 83843, USA;

E-Mail: ddumroese@fs.fed.us

3 Rocky Mountain Research Station, USDA Forest Service, Fort Collins, CO 80526, USA;

E-Mail: dmccollum@ffs.fed.us

4 Missoula Fire Sciences Laboratory, USDA Forest Service, Missoula, MT 59808, USA;

E-Mail: sbaker03@fs.fed.us

5 College of Forestry and Conservation, University of Montana, Missoula, MT 59812, USA;

E-Mails: drloeffler@fs.fed.us (D.L.); woodam.chung@umontana.edu (W.C.)

* Author to whom correspondence should be addressed; E-Mail: nathanielmanderson@fs.fed.us; Tel.: +1-406-329-3398; Fax: +1-406-329-3487.

Received: 18 September 2012; in revised form: 20 December 2012 / Accepted: 2 January 2013 / Published: 8 January 2013

\begin{abstract}
Thermochemical biomass conversion systems have the potential to produce heat, power, fuels and other products from forest biomass at distributed scales that meet the needs of some forest industry facilities. However, many of these systems have not been deployed in this sector and the products they produce from forest biomass have not been adequately described or characterized with regards to chemical properties, possible uses, and markets. This paper characterizes the producer gas, biochar, and activated carbon of a $700 \mathrm{~kg} \mathrm{~h}^{-1}$ prototype gasification system and a $225 \mathrm{~kg} \mathrm{~h}^{-1}$ pyrolysis system used to process coniferous sawmill and forest residues. Producer gas from sawmill residues processed with the gasifier had higher energy content than gas from forest residues, with averages of 12.4 $\mathrm{MJ} \mathrm{m}^{-3}$ and $9.8 \mathrm{MJ} \mathrm{m}^{-3}$, respectively. Gases from the pyrolysis system averaged $1.3 \mathrm{MJ} \mathrm{m}^{-3}$ for mill residues and $2.5 \mathrm{MJ} \mathrm{m}^{-3}$ for forest residues. Biochars produced have
\end{abstract}


similar particle size distributions and bulk density, but vary in $\mathrm{pH}$ and carbon content. Biochars from both systems were successfully activated using steam activation, with resulting BET surface area in the range of commercial activated carbon. Results are discussed in the context of co-locating these systems with forest industry operations.

Keywords: pyrolysis; gasification; biomass; biochar; activated carbon; synthesis gas

\section{Introduction}

\subsection{Background}

Sawmills and other wood products manufacturing facilities produce large quantities of woody biomass in the form of wood chips, sawdust, shavings and bark. These mill residues are commonly sold as raw material for the manufacture of paper and engineered wood panels (e.g., clean chips for pulp and sawdust for particle board), for landscaping applications (e.g., bark mulch), and as fuel for combustion boilers (e.g., hog fuel). The forest sector also produces millions of tons of woody biomass as a byproduct of silvicultural treatments prescribed to harvest timber, manage fire risk, improve forest health, and meet other management objectives. These forest residues include foliage, tops, limbs, unmerchantable roundwood, and stumps, which are frequently burned on site to reduce the risk of wildfires and clear growing space for regeneration. Both mill residues and forest residues are commonly used as fuel in combustion boilers to produce process heat and power for forest industry operations. More than $50 \%$ of all biomass energy in the United States is generated by the forest industry to dispose of waste and provide heat and electricity for manufacturing operations [1]. In some areas, forest biomass is also used to fuel large power plants and distributed heat and power systems [2,3].

Over the last twenty years, a complex interaction of social, political and economic factors has resulted in permanent mill closures in the interior western United States. Declining industry capacity has reduced the demand for forest biomass and increased average haul distances for timber and biomass producers in this region. For example, prior to its closure in December, 2009, the Smurfit-Stone liner board plant in Missoula, MT, used approximately 1.5 million tons of biomass annually, including wood for both pulp and energy [4]. Since the closure, one-way haul distances for mill and forest residues in western Montana have increased from 70 miles or less to 130 to 210 miles, depending on the end user. In general, high transportation costs and weak regional demand for forest biomass negatively impact the financial viability of wood products manufacturing and silvicultural treatments by turning previously marketable byproducts into waste materials with disposal costs. Furthermore, the most widely practiced method of disposal, open burning, can have negative environmental impacts including increased air pollution, establishment of invasive species, and reduced nutrient capital and soil productivity at burn sites $[5,6]$.

Recent technical advances and public policies related to greenhouse gas emissions and energy security have spurred interest in using thermochemical conversion technologies to process forest biomass closer to harvest sites to improve transportation efficiency and produce renewable high-value 
bioproducts that can be more efficiently shipped to distant markets [7]. Specifically, using heat to convert biomass into dense, value-added fuel and chemical products has the potential to improve the financial viability of biomass utilization in locations characterized by long haul distances and weak demand for biomass from pulp mills and other large facilities. Depending on substitutability for existing products, biofuels and bioproducts may also offset fossil fuel use and associated emissions with renewable forest resources, possibly at scales that are well-matched to small and medium sized operations.

In contrast to large-scale centralized facilities that require hundreds of thousands of tonnes of biomass per year, many of the advanced thermochemical technologies currently being developed are targeted at smaller-scale demand for distributed heat and power, biofuels and bioproducts production, and waste processing [8]. In delineating alternative scales of these systems, it is useful to think of distributed scale systems as small, compact, and clean units located at or near an end user of heat and power [9]. Several companies manufacture distributed thermochemical conversion systems, and some have marketed these systems for forest biomass processing [10,11]. Unlike centralized facilities that procure large volumes of biomass from many suppliers across a large geographic area, distributed systems have the potential to allow individual firms to match their byproduct and residues streams with appropriate conversion capacity to produce heat, power, and marketable products from biomass.

\subsection{Objectives}

It is possible to convert forest biomass into heat, producer gas, biochar, and bio-oil at distributed scales using pyrolysis and gasification technology. A large body of research is devoted to laboratory and pilot scale study of pyrolysis and gasification of woody biomass [12-14] and an increasing number of companies are developing and marketing commercial technologies for biomass conversion. However, there are gaps in our understanding of how these technologies differ with regards to outputs and how these systems might be integrated into existing forest products supply chains. Many of these systems have not been deployed in this sector and the products they produce from forest biomass have not been adequately described or characterized with regards to chemical properties, possible uses, and markets. Uncertainty about product quality and potential value represents risk to investment and presents a significant barrier to the adoption of these technologies by private companies.

The objective of this study is to compare two commercially available technologies with regards to the physical and chemical properties of their outputs and associated market products in the context of co-locating these systems with forest industry operations. Specifically, we: (1) use a gasifier and a pyrolysis system to process coniferous mill and forest residues, (2) characterize the gas and biochar produced by each, and (3) evaluate potential uses for those outputs, including the use of biochar as a precursor in the production of activated carbon (AC). This critical new knowledge is needed by technology firms, investors, and managers to evaluate potential markets for pyrolysis and gasification products and to assess the commercial potential and financial feasibility of distributed thermochemical processing deployed in the forest sector. Our results can also be used to inform analysis of the environmental costs and benefits of these products, including life cycle assessment (LCA). 


\subsection{Overview of Pyrolysis and Gasification Products}

Thermochemical conversion can occur across broad ranges of temperature, pressure, heating rate, oxidation conditions, and residence time. Generally, pyrolysis of biomass at 200 to $300{ }^{\circ} \mathrm{C}$ (torrefaction) produces a devolatilized, hydrophobic high-carbon content product often referred to as torrefied wood. Several characteristics of torrefied wood make it more efficient to transport and store than raw biomass, including lower moisture content, higher energy density, hydrophobicity, resistance to decay, and homogenous particle size distribution [15]. It is generally considered a fuel product suitable for combustion applications, including cofiring with coal, but may also be used as a raw material in some manufacturing processes, including gasification and liquid fuel production [16].

Pyrolysis of biomass at higher temperatures $\left(300\right.$ to $\left.700{ }^{\circ} \mathrm{C}\right)$ produces recalcitrant charcoal called biochar, as well as volatile gases, a fraction of which may be condensed into liquid pyrolysis oil, also called bio-oil. Biochar can be used in its raw form as a solid fuel, or used as a feedstock for the production of other products, including chemicals, AC, and soil additives. Similarly, bio-oil can be used in its raw form as liquid fuel. However, because of its high oxygen and water content and low stability, bio-oil is generally considered a crude product to be used in the production of refined (i.e., upgraded) biofuels and industrial chemicals, including liquid transportation fuels [12]. Pyrolysis in this temperature range often produces residual tars which can be a useful output or an undesirable byproduct, depending on production objectives [17].

Depending on the conditions of the reaction, specifically the composition and concentration of gas injected into the system, gasification of biomass at temperatures greater than $700{ }^{\circ} \mathrm{C}$ produces more gas (i.e., producer gas or synthesis gas) and less biochar than pyrolysis, along with some ash. Depending on gas quality, gases from both pyrolysis and gasification have the potential to be used to produce heat and power in an internal combustion or gas turbine engine. The producer gas from gasification can be used to produce liquid fuels and chemicals, including methanol and hydrocarbon fuels via catalytic conversion processes $[18,19]$. In addition to these outputs, if conversion is co-located with wood products manufacturing, excess heat from the conversion process can be used for heating buildings, drying lumber and heat-treating products for export. The two systems evaluated in this study operate at the upper end of the temperature spectrum and produce biochar and gas, but no liquid products.

\section{Methods}

\subsection{Biomass Feedstock}

We processed mill and forest residues from Tricon Timber, LLC, Saint Regis, MT, USA. The mill residues were a byproduct of manufacturing lumber from delimbed, debarked logs, and contained negligible bark and foliage. In contrast, forest residues were produced from field-dried logging slash and included both bark and foliage. Both feedstocks were mixed coniferous species dominated by Douglas-fir (Pseudotsuga menziesii) and lodgepole pine (Pinus contorta). Both feedstocks were chipped and screened to meet particle size specifications of $0.76 \mathrm{~cm}$ to $1.27 \mathrm{~cm}$ with less than $5 \%$ size over run, and then dried in a kiln to a moisture content of $10 \%$ or less before shipping. Prepared feedstocks were shipped to study sites in Colorado and North Carolina in 55 gallon drums that were 
closed but not airtight. Feedstocks in Colorado did not receive additional kiln drying, but feedstocks in North Carolina received $12 \mathrm{~h}$ of additional drying in two portable kilns due to concerns that ambient humidity might increase the moisture content above $10 \%$. The moisture content of the feedstocks at the time of conversion ranged from $5.7 \%$ to $8.2 \%$ (Table 1). At $98.2 \%$ organic matter (OM), the mill residues had higher OM content than forest residues, which were 91.5\% OM (Table 1). Compared to feedstocks from debarked logs, feedstocks containing bark and foliage generally have higher ash content associated with inherent inorganic compounds in the cambium and contamination from soil during harvest and transport [20]. The content of carbon, nitrogen and selected extractable alkaline metals in these feedstocks are shown in Table 1.

Table 1. Feedstock characteristics.

\begin{tabular}{|c|c|c|c|c|c|c|c|c|}
\hline \multirow{2}{*}{ Feedstock } & \multirow{2}{*}{ System } & \multirow{2}{*}{$\begin{array}{c}\text { Moisture } \\
\text { (\%) }^{\text {b }}\end{array}$} & \multirow{2}{*}{$\begin{array}{c}\text { Organic } \\
\text { matter }(\%)\end{array}$} & \multirow{2}{*}{$\begin{array}{c}\text { Mean C } \\
(\%)\end{array}$} & \multirow{2}{*}{$\begin{array}{c}\text { Mean N } \\
(\%) \\
\end{array}$} & \multicolumn{3}{|c|}{ Total extractable cations $\left(\mathrm{mg} \mathrm{kg}^{-1}\right)^{\mathrm{a}}$} \\
\hline & & & & & & $\mathbf{C a}$ & Mg & $\mathbf{K}$ \\
\hline Mill residues & TEA & 8.17 & 98.19 & 47.4 & 0.1566 & 1250.0 & 146.5 & 577.5 \\
\hline Mill residues & BSI & 7.04 & $\mathrm{c}$ & 47.4 & 0.2062 & 1919.6 & 296.4 & 781.0 \\
\hline Forest residues & TEA & 5.71 & 91.51 & 45.8 & 0.2904 & 1299.6 & 396.3 & 898.4 \\
\hline Forest residues & BSI & 7.25 & $\mathrm{c}$ & 48.4 & 0.2124 & 2405.8 & 290.5 & 1097.6 \\
\hline
\end{tabular}

${ }^{\mathrm{a}}$ Units of $\mathrm{mg} \mathrm{kg}^{-1}$ are equivalent to parts per million (ppm); ${ }^{\mathrm{b}}$ Moisture content at the time of conversion. All feedstocks were kiln dried to less than $10 \%$ before shipping. Feedstocks for the TEA system received an additional $12 \mathrm{~h}$ of kiln drying before conversion; ${ }^{\mathrm{c}}$ Unknown.

\subsection{Conversion}

These feedstocks were processed using a prototype gasification system manufactured by Tucker Engineering Associates (TEA), Locust, NC, USA (Figure 1), and a modular pyrolysis system manufactured by Biochar Solutions, Incorporated (BSI), Carbondale, CO, USA (Figure 2, [21]).

Figure 1. The Tucker Engineering Associates (TEA) gasifier used in this study. Photo: RMRS.

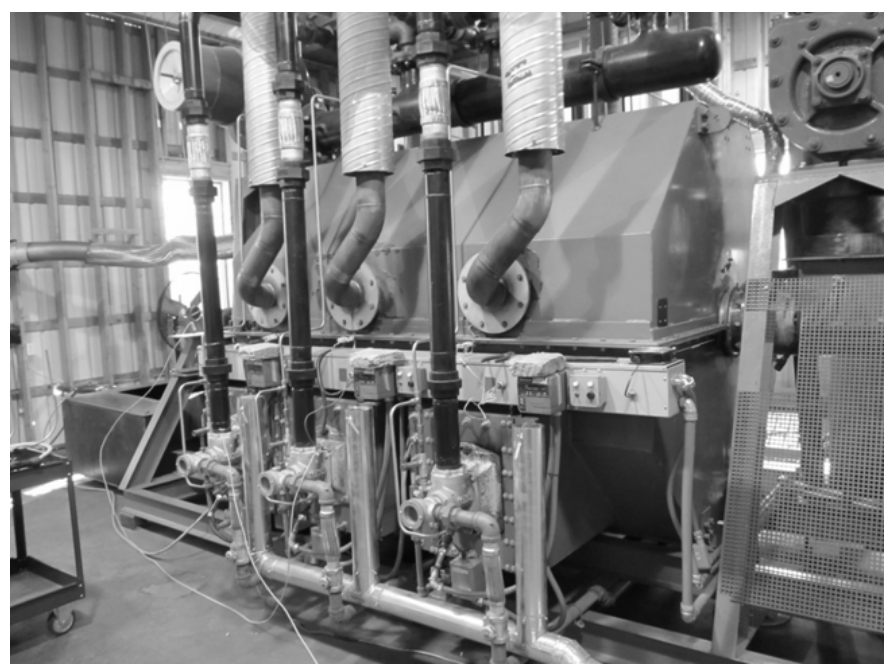


Figure 2. The Biochar Systems Incorporated (BSI), pyrolysis system Beta model used in this study. The unit used in this study was fitted with a thermal oxidizer (not shown), which replaces the open flare shown on the right. Photo: BSI.

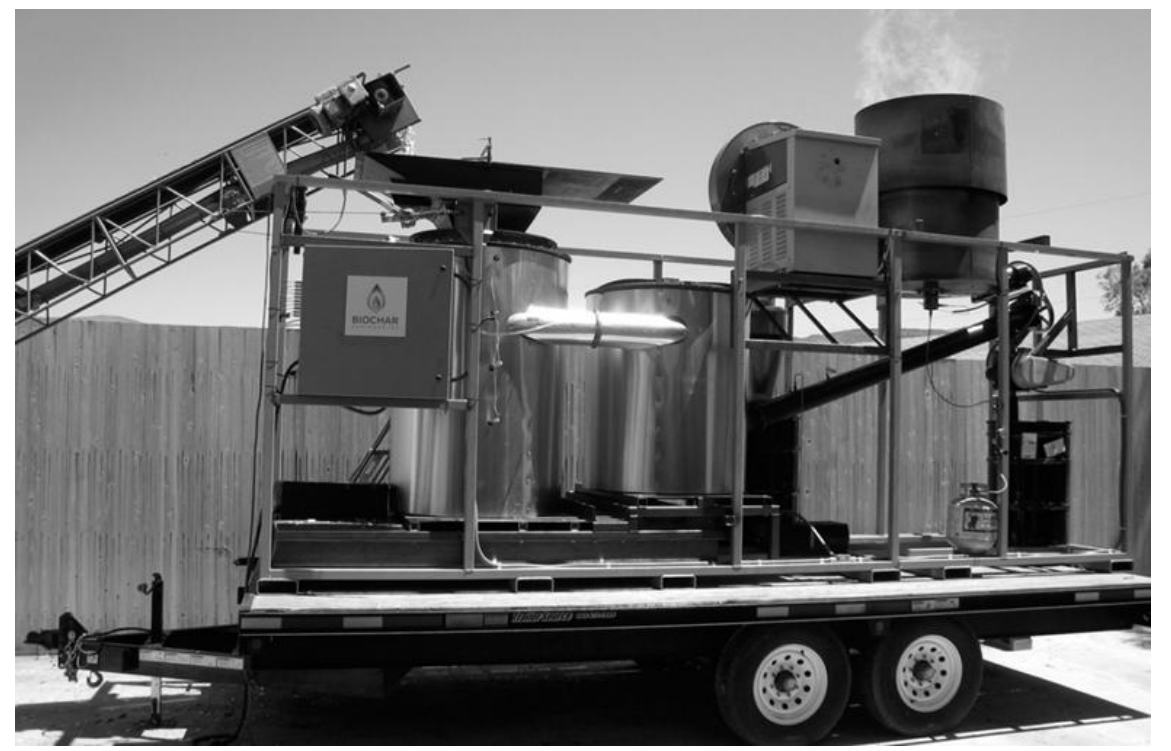

The operational dry weight feedstock throughputs of the two systems have been estimated by the manufacturers to be $700 \mathrm{~kg} \mathrm{~h}^{-1}$ and $225 \mathrm{~kg} \mathrm{~h}^{-1}$, respectively. Biochar yields by mass are reported as between $5 \%$ and $25 \%$ for the TEA system and up to $24 \%$ for the BSI system, with the balance going to producer gas and a small fraction of ash and tar byproducts.

The TEA system was engineered to produce high-quality, high-energy gas from a wide range of feedstocks including coal, municipal solid waste, and wood waste. Biochar is considered a co-product of gas production. The TEA biochars were carbonized at $1040{ }^{\circ} \mathrm{C}$ in a direct heat, screw conveyor reactor heated by six tangential burners fueled with propane. With feedstock airlocks and no inputs of oxygen, steam, or carrier gas during the conversion process, oxidation during conversion was very low. The pyrolysis gas pressurizing the system is primarily carbon monoxide, nitrogen, methane, and hydrogen. Residence time is estimated at 1.5 min per run. Results for TEA biochars below are for a "double run", where the feedstock was run through the system to produce biochar, and then the resulting biochar output was run through the system again to remove any residual volatiles and simulate a longer auger configuration, which is currently in development by TEA. Total residence time in this study was approximately $3.0 \mathrm{~min}$. Samples from twelve runs were collected over six days of operation.

The BSI pyrolysis system was engineered to produce biochar from biomass, including agricultural residues and wood waste, with a focus on achieving high yields of biochar with a high percentage of stable, recalcitrant carbon. Energy gas and heat are generally considered co-products of biochar production. The BSI system uses a two-stage reactor. In the primary reactor, the feedstock is carbonized in a controlled aerobic environment with limited oxygen at a temperature between 700 and $750{ }^{\circ} \mathrm{C}$ for less than one minute. Then the material passes into a second reactor, where material is held in a sweep gas environment for approximately ten to fifteen minutes at a temperature between 400 and $550{ }^{\circ} \mathrm{C}$, before the material is removed from the machine by a liquid cooled auger with an air lock. The dust fraction of biochar present in the gas stream is collected by a cyclone trap before the gas is 
evacuated from the system by a blower. Dust does not receive the same sweep gas treatment as the coarse biochar output, which receives full residence time in the second reactor. The dust fraction of production is not characterized in this study. The pyrolysis gas produced during the first stage of pyrolysis is used as sweep gas for the second stage and is pulled through the system by a blower. This gas is composed primarily of carbon monoxide, nitrogen, methane, and hydrogen, with some oxygen. Some limited oxidation occurs in the first stage, but oxidation is very low in the second stage. Samples from four runs were collected on a single day of operation.

\subsection{Sampling and Laboratory Analysis}

During conversion, samples of producer gas were collected in $0.5 \mathrm{~L}$ evacuated, inert steel canisters, which were pressurized to 15 psig (gauge pressure in pound per square inch) using stainless steel flexible tubing and a battery powered pump apparatus. Each sample generally represents about 15 to $30 \mathrm{~s}$ of gas flow. For both systems, tubing was attached to air-tight sampling ports located between the reactor and the downstream air lock system, which is an enclosed, pressurized water tank on the TEA system and a blower and cyclone on the BSI system. In total, twenty-five gas samples were collected from the two systems representing eight runs of each feedstock.

In the laboratory, canister samples of producer gas were analyzed for $\mathrm{CO}_{2}, \mathrm{CO}, \mathrm{CH}_{4}$, and $\mathrm{C} 2$ and C3 hydrocarbon gases with an Agilent model 7890 gas chromatograph configured with two columns running simultaneously. Chromatogram data were collected and processed by Agilent Chem Station software. A set of gas standards bracketing the sample concentrations were analyzed with each set of samples to construct a standard curve for each compound. Based on the integrated peak areas, the sample concentrations were calculated from the standard curves and written into a spreadsheet for analysis.

For measurement of $\mathrm{H}_{2}$ concentrations, a Trace Analytical RGA3 gas analyzer was used. A molecular sieve column and a mercuric oxide reduction gas detector were used to measure trace levels of $\mathrm{CO}, \mathrm{H}_{2}$ and other reduction gases. The detection limit is $0.1 \mathrm{ppm} \mathrm{H}_{2}$. Data from this instrument were also collected and processed by Agilent Chem Station software. Calculations of energy content of the producer gas were made using standard stoichiometric techniques applied to the concentrations of combustible gas components.

At the time of conversion, feedstock and biochar samples were packaged in zip-type bags and shipped to the laboratory for analysis. Four $1.0 \mathrm{~kg}$ feedstock samples (two of each type) and fifteen $2.0 \mathrm{~kg}$ biochar samples were collected. Two additional biochar samples, approximately $10 \mathrm{~kg}$ each, were packaged for use as a precursor in steam activation trials. Feedstock moisture content was determined in the laboratory using oven drying at $103 \pm 2{ }^{\circ} \mathrm{C}[22]$. Feedstock samples were analyzed for organic matter content using loss-on-ignition methods for 8 hours duration at $400{ }^{\circ} \mathrm{C}$ [23]. To obtain nutrient information, feedstock samples were ashed for $5 \mathrm{~h}$ at $475{ }^{\circ} \mathrm{C}$ and nutrients were extracted with a $2 \mathrm{~N}$ nitric acid solution. The extractable nutrients calcium, magnesium and potassium were determined by analysis with a Perkin Elmer 5100PC Atomic Absorption Spectrometer (Perkin Elmer, Inc., Waltham, MA, USA).

A sieve analysis was used to determine the particle size distribution of each biochar product. Using a mechanical shaker, a $100 \mathrm{~g}$ biochar sample was passed through successively smaller screens with 
opening sizes ranging from 6.35 to $0.044 \mathrm{~mm}$. An unconsolidated biochar sample was used to assess sample $\mathrm{pH}$. A biochar-distilled water solution with a 1:4 ratio was made and $\mathrm{pH}$ of the solution was determined with an Orion 4-Star meter and electrode (Thermo Scientific, Beverly, MA, USA).

The determination of total carbon and total nitrogen for both the feedstocks and biochars was made by dry combustion on a TruSpec $\mathrm{CN}$ analyzer, which uses an infrared detector to measure carbon and a thermal conductivity cell to determine nitrogen (Leco Corporation, St. Joseph, MI, USA). Samples were dried and homogenized prior to analysis and feedstocks were ground to pass through a $420 \mu \mathrm{m}$ screen. Biochar was ground into a fine powder. Differences in analytical methods reflect the unique composition of the samples - feedstocks were treated as organic material while the biochar was analyzed using soil (i.e., mineral) methods with higher oxygen flow during the burn phase to ensure complete combustion of the material. Energy content was determined by calorimetry using a Parr bomb calorimeter calibrated with a standard of benzoic acid. Total carbon and nitrogen associated with this test was measured with a LECO CN analyzer.

Two physical activation methods were used to activate biochar outputs from the BSI and TEA systems. Biochars from both systems were activated with steam using a bench top steam activation apparatus. Activation temperature was $950{ }^{\circ} \mathrm{C}$, with steam injected at $15 \mathrm{psig}$. In addition, the TEA system biochars were activated using a 6.5 inch internal diameter electrically heated Bartlett-Snow rotary calciner (Alstom Power, Naperville, IL, USA). The calciner has four zones along the furnace section for temperature control and the hottest zones were set at $927{ }^{\circ} \mathrm{C}$. The calciner cylinder was nitrogen purged to maintain an inert atmosphere prior to activation and steam was injected at $815^{\circ} \mathrm{C}$. Retention time was $45 \mathrm{~min}$. Unfortunately, due to cost and logistical considerations, BSI biochars were not activated using this method.

Iodine number for biochars and AC was calculated using titration methods, specifically ASTM D4607-94 [24]. Brunauer-Emmet-Teller (BET) surface area of TEA biochars and resultant AC produced from TEA biochar precursor was measured by nitrogen gas sorption analysis at $77 \mathrm{~K}$ using a BET-201-APC Sorptometer (Porous Materials Incorporated, Ithaca, NY, USA). Before analysis, $1.0 \mathrm{~g}$ samples were vacuum outgassed to $20 \mu \mathrm{m}$ at $20{ }^{\circ} \mathrm{C}$, with variable outgassing time. In addition to BET surface area, sorption analysis was used to calculate total pore volume, porosity, and several measures of pore diameter for TEA biochars and AC.

\section{Results}

For both feedstocks, producer gas from the TEA gasification system has higher energy content than that of the BSI system (Figure 3). This is a result of higher concentrations of hydrogen, carbon monoxide, and $\mathrm{C} 2$ hydrocarbons, including ethane $\left(\mathrm{C}_{2} \mathrm{H}_{6}\right)$, ethylene $\left(\mathrm{C}_{2} \mathrm{H}_{4}\right)$, and acetylene $\left(\mathrm{C}_{2} \mathrm{H}_{2}\right.$, Table 2). Among the $\mathrm{C} 2$ hydrocarbons, ethylene is the most prevalent $\mathrm{C} 2$ gas for both systems (Table 3). However, the proportion of acetylene among the three is higher for the TEA system than for the BSI system. Concentrations of methane appear similar for the two systems, as do concentrations of C3 and C4-C5 hydrocarbons, which combined are below $0.25 \%$ for both systems. Other gasses, primarily nitrogen and water vapor, account for a larger fraction of producer gas from the BSI system. For the TEA system, gas from mill residues had higher energy content than gas from forest residues, 
with averages of $12.4 \mathrm{MJ} \mathrm{m}^{-3}$ and $9.8 \mathrm{MJ} \mathrm{m}^{-3}$, respectively. Gases from the BSI system were $1.3 \mathrm{MJ} \mathrm{m}^{-3}$ for mill residues and $2.5 \mathrm{MJ} \mathrm{m}^{-3}$ for forest residues.

Figure 3. Gas energy content.

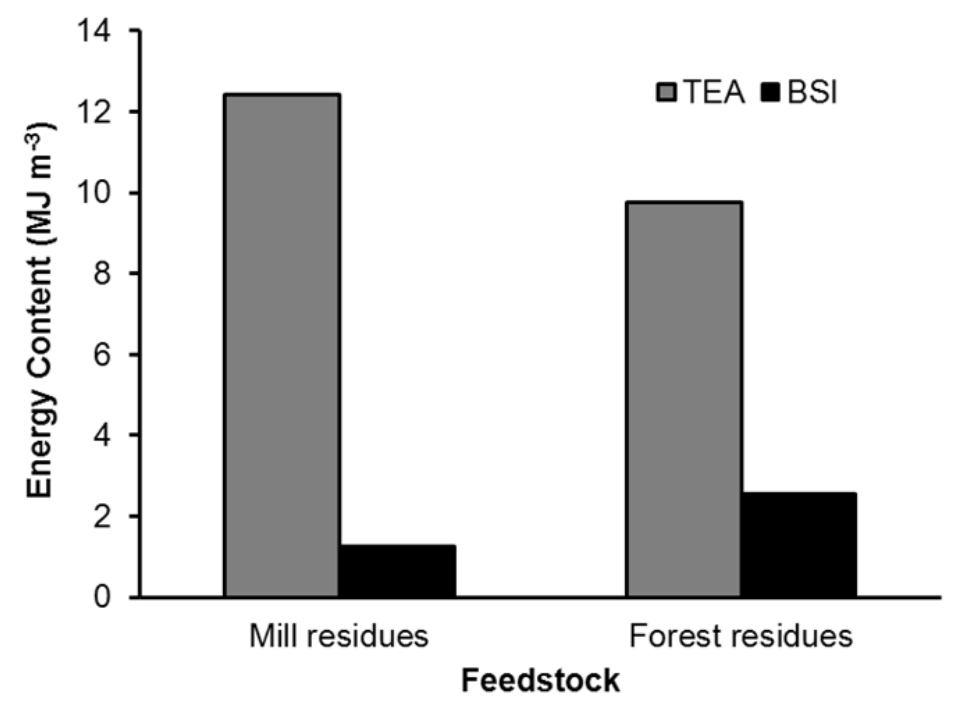

Table 2. Producer gas chemical composition.

\begin{tabular}{ccccc}
\hline \multirow{2}{*}{ Feedstock } & \multicolumn{2}{c}{ Mill residues } & \multicolumn{2}{c}{ Forest residues } \\
\cline { 2 - 5 } Constituent/System & TEA & BSI & TEA & BSI \\
\hline $\mathrm{H}_{2}(\%)$ & 8.46 & 1.84 & 7.39 & 2.63 \\
$\mathrm{CO}(\%)$ & 39.03 & 4.04 & 34.05 & 7.83 \\
$\mathrm{CO}_{2}(\%)$ & 7.66 & 0.89 & 5.97 & 1.90 \\
$\mathrm{CH}_{4}(\%)$ & 12.68 & 7.35 & 10.38 & 12.08 \\
$\mathrm{C}_{2}(\%)$ & 3.43 & 0.24 & 1.63 & 0.64 \\
$\mathrm{C}_{2} \mathrm{H}_{6}(\%)$ & 0.14 & 0.08 & 0.03 & 0.15 \\
$\mathrm{C}_{2} \mathrm{H}_{4}(\%)$ & 2.77 & 0.15 & 1.18 & 0.44 \\
$\mathrm{C}_{2} \mathrm{H}_{2}(\%)$ & 0.51 & 0.01 & 0.42 & 0.05 \\
$\mathrm{C}_{3}(\%)$ & 0.06 & 0.07 & 0.01 & 0.17 \\
$\mathrm{C}_{4}-\mathrm{C} 5(\%)$ & 0.00 & 0.02 & 0.00 & 0.05 \\
Other $(\%)$ & 28.68 & 85.55 & 40.57 & 74.69 \\
\hline
\end{tabular}

Table 3. Biochar characteristics.

\begin{tabular}{cccccccccc}
\hline Feedstock & System & $\begin{array}{c}\mathbf{H}_{\mathbf{2}} \mathbf{O} \\
\mathbf{( \% )}\end{array}$ & $\begin{array}{c}\text { Bulk density, } \\
\mathbf{d r y}\left(\mathbf{M g ~ m}^{-\mathbf{3}}\right)\end{array}$ & $\mathbf{p H}$ & $\mathbf{C ~ ( \% )}$ & $\mathbf{N}(\mathbf{\%})$ & $\mathbf{C : N}$ & $\begin{array}{c}\text { BET surface } \\
\mathbf{a r e a}_{\left(\mathbf{m}^{2} \mathbf{g}^{-\mathbf{1}}\right)}\end{array}$ & $\begin{array}{c}\text { Energy } \\
\left.\mathbf{( M J ~ k g}^{-\mathbf{1}}\right)\end{array}$ \\
\hline Mill residues & TEA & 2.94 & 0.165 & 10.2 & 91.5 & 0.89 & 102.8 & 15.0 & 33.98 \\
Mill residues & BSI & 1.31 & 0.150 & 9.0 & 82.1 & 0.83 & 98.9 & 203.0 & 35.71 \\
Forest residues & TEA & 1.68 & 0.183 & 8.9 & 70.5 & 0.81 & 87.0 & 11.8 & 33.40 \\
Forest residues & BSI & 2.23 & 0.131 & 8.7 & 75.9 & 0.45 & 168.7 & 129.0 & 33.46 \\
\hline
\end{tabular}

Biochars produced by the two systems from screened feedstocks show similar particle size distributions (Figure 4), which are centered around $0.84 \mathrm{~mm}$ and skewed toward smaller particle sizes. TEA system biochars from forest residues appear to have a larger proportion of particles in the smaller 
than $0.42 \mathrm{~mm}$ size classes. Bulk densities for the samples are also similar and range from $0.131 \mathrm{Mg} \mathrm{m}^{-3}$ to $0.183 \mathrm{Mg} \mathrm{m}^{-3}$ (Table 3), which are relatively low for wood biochars and reflect the low densities of the softwood feedstocks [25]. All of the biochars produced were alkaline, with biochars from mill residues having a higher $\mathrm{pH}$ than those from forest residues. Average $\mathrm{pH}$ ranges from a low of 8.7 for BSI biochar made from forest residues to 10.2 for TEA biochars made from mill residues.

Figure 4. Biochar particle size distribution.
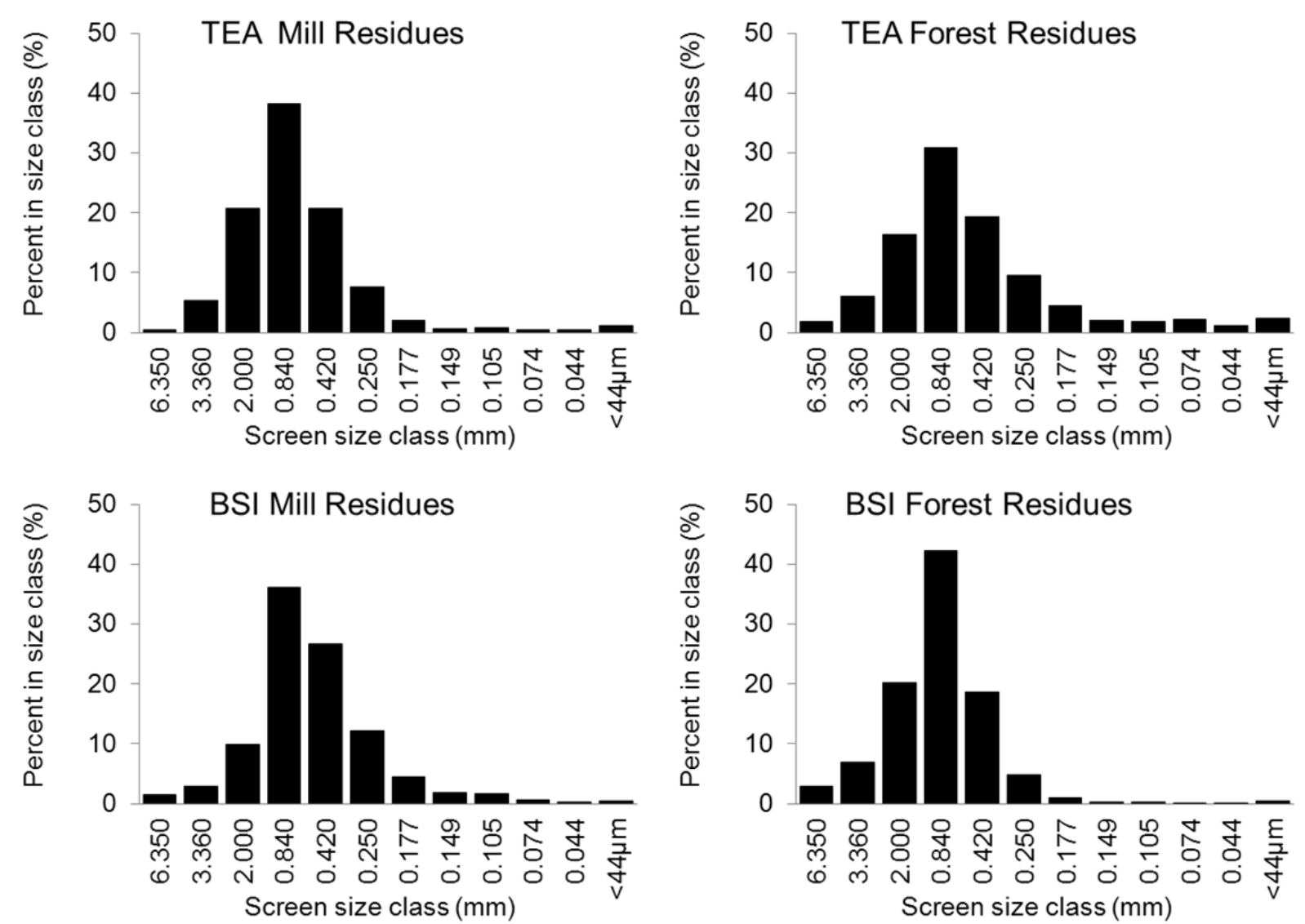

At $15.0 \mathrm{~m}^{2} \mathrm{~g}^{-1}$ (TEA) and $203.0 \mathrm{~m}^{2} \mathrm{~g}^{-1}$ (BSI), mill residue biochars also have slightly higher BET surface areas than forest residue biochars, which are $11.8 \mathrm{~m}^{2} \mathrm{~g}^{-1}$ and $129.0 \mathrm{~m}^{2} \mathrm{~g}^{-1}$ for the TEA and BSI systems, respectively. Carbon content for the TEA system biochars made from mill and forest residues are $91.5 \%$ and $70.5 \%$, compared to $82.1 \%$ and $75.9 \%$ for BSI biochars. The carbon to nitrogen ratio for these biochars ranges from 87.0 to 168.7 . The energy contents of these biochars on a dry weight basis are similar and range from 33.4 to $35.7 \mathrm{MJ} \mathrm{kg}^{-1}$.

Pre-activation iodine numbers were $7 \mathrm{mg} \mathrm{g}^{-1}$ and $2 \mathrm{mg} \mathrm{g}^{-1}$ for TEA biochars and 142 and $82 \mathrm{mg} \mathrm{g}^{-1}$ for BSI biochars, for mill and forest residues, respectively. Following bench top steam activation at $950{ }^{\circ} \mathrm{C}$ with steam injected at $15 \mathrm{psig}$, iodine number ranged from $245 \mathrm{~g} \mathrm{cg}^{-1}$ to $425 \mathrm{~g} \mathrm{cg}^{-1}$, indicating a significant increase in adsorption properties (Figure 5). For the bench top apparatus, AC from BSI biochars have higher iodine adsorption than AC from TEA biochars. It also appears that mill residues produce AC with higher adsorption potential. For TEA system biochars, AC iodine adsorption for mill residue feedstock is $29 \%$ higher than for forest residue feedstock. The difference is much smaller 
$(<3 \%)$ for the BSI system. BET surface area was not calculated for AC produced using bench top steam activation.

Figure 5. Iodine number of $\mathrm{AC}$ from biochar using a benchtop steam activation apparatus at $950{ }^{\circ} \mathrm{C}$ with steam injected at 15 psig.

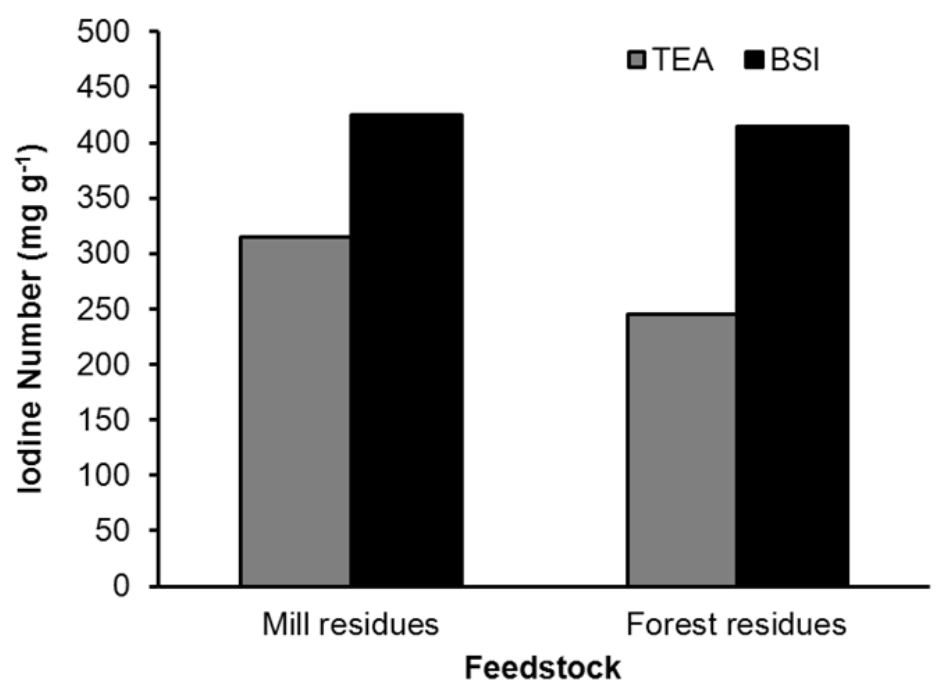

In addition to bench top activation, TEA system biochars were activated using a Bartlett-Snow rotary calciner at $927^{\circ} \mathrm{C}$ with activation by steam injected at $815^{\circ} \mathrm{C}$. Results show that this method of activation increased BET surface area from $15.0 \mathrm{~m}^{2} \mathrm{~g}^{-1}$ to $1283.0 \mathrm{~m}^{2} \mathrm{~g}^{-1}$ for biochar made from mill residues and from $11.0 \mathrm{~m}^{2} \mathrm{~g}^{-1}$ to $575.9 \mathrm{~m}^{2} \mathrm{~g}^{-1}$ for biochar made from forest residues (Table 4). The increase in surface area is reflected by the pore characteristics of the AC, with large increases in total pore volume and porosity, and a decrease in average pore diameter (Table 4).

Table 4. BET surface area and pore characteristics of TEA system biochars and AC resulting from steam activation in a rotary calciner at $815^{\circ} \mathrm{C}$.

\begin{tabular}{cccccccc}
\hline Feedstock & Product & $\begin{array}{c}\text { BET surface } \\
\left(\mathbf{m}^{\mathbf{2}} \mathbf{g}^{-\mathbf{1}} \mathbf{)}\right.\end{array}$ & $\begin{array}{c}\text { Total pore } \\
\text { volume } \\
\left(\mathbf{c c ~ g}^{-\mathbf{1}}\right)\end{array}$ & $\begin{array}{c}\text { Porosity (per } \\
\text { g of sample) }\end{array}$ & $\begin{array}{c}\text { Ave. pore } \\
\text { diameter }(\mathbf{\AA})\end{array}$ & $\begin{array}{c}\text { Med. PV } \\
\text { pore dia. }(\mathbf{\AA})\end{array}$ & $\begin{array}{c}\text { Med. SA } \\
\text { pore dia. }(\AA)\end{array}$ \\
\hline Mill residues & Biochar & 15.0 & 0.0161 & 0.0158 & 42.79 & 45.90 & 35.97 \\
Forest residues & Biochar & 11.8 & 0.0359 & 0.0347 & 122.09 & 175.98 & 60.92 \\
Mill residues & AC & 1283.0 & 0.9591 & 0.4895 & 29.90 & 48.15 & 26.97 \\
Forest residues & AC & 575.9 & 0.4441 & 0.3075 & 30.85 & 51.32 & 27.28 \\
\hline
\end{tabular}

\section{Discussion}

This study examines the chemical and physical properties of the outputs of two different thermochemical conversion technologies used to process mill and forest residues, with an emphasis on potential uses and markets for those outputs. The two systems were chosen because they are commercially available, can process a wide range of woody biomass feedstocks of varying quality, and are small enough to be used in distributed applications by small and medium scale forest industry facilities. The two systems also represent different ends of the conversion spectrum, with the BSI 
pyrolysis system designed to maximize biochar fixed carbon and sorption for an exothermic reaction between 350 and $750{ }^{\circ} \mathrm{C}$, and the TEA system gasifier designed to produce high-energy gas at temperatures greater than $1000{ }^{\circ} \mathrm{C}$. The differences between the systems are reflected in differences between production outputs and their potential uses and markets.

\subsection{Producer Gas}

The energy content of gas produced from forest biomass by the TEA system gasifier is somewhat higher than values reported in studies of pilot scale and laboratory systems. For example, using a Biomax-25 gasifier (Community Power Corporation, Littleton, CO, USA), Elder and Groom [26] produced gas from pine and mixed hardwood chips with energy content around $6 \mathrm{MJ} \mathrm{m}^{-3}$. Son et al. [27] reported syngas energy content of $4.6 \mathrm{MJ} \mathrm{m}^{-3}$ for wood chips processed in an experimental downdraft gasifier. At $12.4 \mathrm{MJ} \mathrm{m}^{-3}$, the TEA system gas produced from mill residue in this study has relatively high energy content. The energy content of BSI pyrolysis system gas is below 3.0 $\mathrm{MJ} \mathrm{m}^{-3}$, which is relatively low compared to gasification systems, but similar to gas produced by pyrolysis systems operating in this temperature range [28]. It would be expected that mill residue feedstocks would result in gas with higher energy content than forest residue feedstocks because of the lower ash content and higher energy density of the raw materials, and this appears to be the case for the TEA system. However, we do not know if the seemingly contrary results of for the BSI system are within the range of variability of the system or represent a statistically significant difference between the feedstocks.

High concentrations of $\mathrm{CO}_{2}$ and $\mathrm{N}_{2}$ are responsible for the lower energy content of the BSI gas. However, it is also worth noting that the BSI system is exothermic and does not require any gas inputs for heating once the primary reactor is fired. By contrast, the TEA reactor is endothermic and is estimated to consume about $1500 \mathrm{MJ} \mathrm{h}^{-1}$ in process heat, which was provided by propane in this study. Using woody biomass feedstocks, process energy needs could be met with about $15 \%$ of the gas production of the TEA system. Though the prototype is not presently configured to use producer gas as fuel for its six tangential burners, TEA is currently modifying the system to integrate this option as part of ongoing research and development.

There are some operational considerations related to air-fuel ratios and lower flame temperature, but in general retrofitting gas burners to accommodate producer gas from biomass conversion is relatively straight forward. This means that, with relatively little cost, the gas produced by these systems can be combusted to produce process heat for mill operations such as feedstock and lumber drying, heat treating, and facility heating. For example, many conversion systems require feedstock with low moisture content, but feedstock moisture content less than $10 \%$ is below what could be expected from field-dried forest residues in most parts of the country. Both systems can be configured to use waste heat and/or combustion of a portion of the gas stream to dry feedstock. BSI currently offers this option for new pyrolysis systems. Mills that dry solid wood products to meet product specifications or export requirements also have a significant need for heat.

Producer gas can also be used as fuel for electricity generation using an internal combustion or turbine engine, but this application is highly dependent on gas quality. Specifically, particulate matter and tars significantly increase engine wear and must be removed though gas cleaning. Gas quality for 
use in turbine engines must be especially high, with narrow parameters for particulate matter $(<30 \mathrm{ppm})$, particle size $(<5 \mu \mathrm{m})$, and alkali metals $<0.2 \mathrm{ppm}$ [28]. Reductions in engine power (i.e., derating) are also a challenge when substituting biomass producer gas for natural gas or liquid fossil fuel because of its lower energy density. Though we did not evaluate these gas properties in this study, the need for significant producer gas post-processing for power generation is likely. However, if power is generated, these systems provide another potential market product-electricity to the grid. If power generation meets facility requirements, excess power may be sold or credited against future power use, depending on grid infrastructure and utility sector regulation.

Biomass is the only renewable energy source that can be used as raw material in the production of liquid hydrocarbon fuels and chemicals. Thermochemical conversion systems are associated with two general types of liquid outputs: bio-oil and liquids manufactured from producer gas. Neither of the two systems in this study produces liquid output, but some pyrolysis systems do produce bio-oil, which could be shipped in its raw form to a refining facility [7]. Industrial systems for the production of methanol (methyl alcohol) from biomass producer gas with high concentrations of $\mathrm{CO}$ and $\mathrm{H}_{2}$ (i.e., synthesis gas) are well established [18]. Furthermore, the development of methods for the commercial production of liquid fuels and chemicals using Fischer-Tropsch (FT) synthesis of biomass producer gas is progressing [19] and even commercialized in some cases [29]. However, a variety of challenges related to economies of scale in refining operations and the technical demands of liquid fuel production make it unlikely that small-scale catalytic production of liquid fuels and chemicals will be integrated directly into these systems in the near future. For both methanol production and FT synthesis, the major barriers to integration at distributed scales are both technical and financial [19].

\subsection{Biochar}

Biochars produced by the TEA and BSI systems can be used as a solid fuel. Recent research on the use of torrefied wood and biochar as fuel has focused on utility applications, especially co-firing with coal [30,31]. Fossil coal energy content is generally higher than that of biochar and ranges from 28 to $40 \mathrm{MJ} \mathrm{kg}^{-1}$, depending on coal quality. In contrast, the calorific value of fuels produced by pyrolysis of wood biomass have been reported as $20.7 \mathrm{MJ} \mathrm{kg}^{-1}$ for torrefied wood [16], between 22.8 and $31.8 \mathrm{MJ} \mathrm{kg}^{-1}$ for slow pyrolysis biochar (i.e., charcoal, [32]), and 20 to $26 \mathrm{MJ} \mathrm{kg}^{-1}$ for biochars made from various woody materials [33,34]. With energy content above $30 \mathrm{MJ} \mathrm{kg}^{-1}$, the biochars evaluated in this study are higher in energy than these fuels, but lower than medium and high quality coal. This means that biochar, like biomass, is generally a poor substitute for coal in terms of energy content. However, there may be other reasons that utility companies and other coal users may want to substitute biochar for coal. Among them, co-firing biochar with coal may reduce fuel costs, reduce some types of emissions (e.g., sulfur oxide and nitrogen oxide), diversify fuel sources, and offset fossil fuels with renewable fuels [35]. In some states, cofiring may also meet requirements for renewable portfolio standards. Whether or not cofiring reduces greenhouse gas emissions depends on the source of the feedstock as well as the carbon accounting methods used, but it is clear that cofiring substitutes biogenic emissions for fossil fuel emissions. In addition, forests supplying biomass for cofiring recover emissions over time through regrowth of harvested stands, as long as forests are not converted to other land uses. 
In general, these benefits are similar to those of cofiring biomass directly without conversion. Some types of coal-fired boilers, including stoker boilers and pulverized coal boilers, can substitute raw biomass for coal, often up to $20 \%$ by mass, without significant detrimental effects on system performance [36], but there may be some advantages to using pyrolysis products in these systems rather than biomass. The energy density of pyrolysis products is higher than that of biomass, which is typically around $16 \mathrm{MJ} \mathrm{kg}^{-1}$ for biomass used in cofiring [37]. In addition to improving transportation efficiency and boiler performance through higher energy density, biochar and torrefied wood have better handling and storage properties than biomass [15]. Furthermore, boiler systems that cannot cofire biomass directly, such as integrated gasification combined cycle systems, may be capable of substituting biochar directly for coal, depending on biochar properties. Based on the particle size distributions and other properties of the biochars produced in this study, we believe that they could be substituted for coal in most gasification applications.

The use of biochar as a soil amendment is the subject of intensifying scientific inquiry from researchers in agriculture, forestry, mining, and other fields. Biochar additions have received the most attention from efforts to increase carbon sequestration while reducing atmospheric carbon dioxide concentrations [38]. Increases in carbon sequestration can improve overall soil quality because of the role that carbon plays in chemical, biological, and physical soil processes [39]. Biochar has a higher surface area and greater porosity than native soil organic matter, which also helps improve soil aggregation. Application of biochar from forest biomass to forest sites can improve the nutrient and water holding capacity of the soil by altering soil texture, aggregation, and organic matter content [40,41]. Biochar can also decrease nutrient leaching and increase nutrient availability by altering soil cation exchange capacity and soil $\mathrm{pH}$ [42]. Understanding the interactions of biochar application and soil texture, organic matter, and $\mathrm{pH}$ will be the key to determining both long-term impacts and potential market opportunities.

It is difficult to evaluate the use of our biochars for soil applications because most chemical data available for biochar soil amendments are based on agricultural crop feedstocks (e.g., peanut hulls, pecan shells, apricot stones) with little information on woody feedstock biochar. As a benchmark, biochar produced from hardwood forest residues by fast pyrolysis and used in forest soil studies contained $62 \% \mathrm{C}$ and $18 \% \mathrm{~N}$, with a $\mathrm{pH}$ of 6.8 and a bulk density of $0.25 \mathrm{Mg} \mathrm{m}^{-3}$ [43]. In comparison to the biochars produced in this study, these chars have higher $\mathrm{C}$, higher $\mathrm{N}$, lower $\mathrm{pH}$, and higher bulk density (Table 3).

The greatest impact of biochar additions to forest soil may be the liming effect that occurs as a result of increased $\mathrm{pH}$. Biochar $\mathrm{pH}$ ranged from 8.7 to 10.2 for this study (Table 3). Forest soils generally have a $\mathrm{pH}$ range from 4.5 to 6.0 . In this case, the liming effect may not be ideal for all forest soil types and plant communities. Many forest plants, fungi, and bacteria thrive at lower soil $\mathrm{pH}$ [44]; therefore altering forest soil $\mathrm{pH}$ through the addition of biochar may result in unfavorable shifts in above- and belowground flora. However, there are currently not any guidelines on the amounts of biochar that can be added before a resultant $\mathrm{pH}$ shift occurs, as this will likely be soil-specific. Low application rates (e.g., 1 to $2 \mathrm{Mg} \mathrm{ha}^{-1}$ biochar), which mimic the amount of biomass removed during harvest operations, may have little impact on soil $\mathrm{pH}$, but would alter water holding and nutrient cycling conditions enough to improve forest growth. On degraded forest lands (e.g., log landings, skid trails) biochar may reduce soil bulk density and increase plant available nutrients sufficiently to 
rehabilitate the soil and ensure native vegetation regrowth [45]. Though field research is progressing rapidly, markets for biochar as a soil amendment are still emerging.

In contrast, markets for AC are well developed and diverse. The chemical and physical properties of carbon that result in improved nutrient and water holding capacity in some soils are also desirable properties for industrial sorbents. High surface area and high porosity are ideal for adsorbing contaminants from both liquids and gases. Physical and chemical activation methods can significantly improve these properties in biochars, potentially adding value by meeting commercial specifications for AC used in filtering applications. Table 5 summarizes published results of BET surface areas and other properties of AC produced from fossil coal and biomass feedstocks. Pollard et al. [46] reported that most commercial ACs have a surface area between 400 and $1600 \mathrm{~m}^{2} \mathrm{~g}^{-1}$.

Table 5. Published BET surface areas of AC produced from fossil coal and biomass feedstocks.

\begin{tabular}{|c|c|c|c|c|c|c|c|}
\hline Feedstock & $\begin{array}{c}\text { BET surface } \\
\left(\mathrm{m}^{2} \mathrm{~g}^{-1}\right)\end{array}$ & $\begin{array}{c}\text { Pyrolysis } \\
\text { temp. }\left({ }^{\circ} \mathrm{C}\right)\end{array}$ & Activat. type & $\begin{array}{c}\text { Activat. } \\
\text { temp. }\left({ }^{\circ} \mathrm{C}\right)\end{array}$ & $\begin{array}{c}\text { Pore volume } \\
\left(\mathrm{cm}^{3} \mathrm{~g}^{-1}\right) \\
\end{array}$ & $\begin{array}{l}\text { Iodine \# } \\
\left(\mathrm{mg} \mathrm{g}^{-1}\right) \\
\end{array}$ & Source \\
\hline Subbituminous coal & 988 & $700-950$ & $\mathrm{CO}_{2}$ & 750 & 0.482 & $\mathrm{a}$ & {$[47]$} \\
\hline Bituminous coal & 536 & 500 & $\mathrm{H}_{3} \mathrm{PO}_{4}$ & 50 & 0.030 & $\mathrm{a}$ & {$[48]$} \\
\hline Apricot stones & 566 & 200 & $\mathrm{H}_{2} \mathrm{SO}_{4}$ & 200 & a & 548 & [49] \\
\hline Wood & 1780 & 440 & $\mathrm{H}_{3} \mathrm{PO}_{4}+$ Steam & 440 & 0.130 & $\mathrm{a}$ & {$[50]$} \\
\hline
\end{tabular}

In this study we show that the biochar produced by the BSI and TEA systems is suitable for physical activation using standard physical activation methods. The TEA AC is within the commercial range, and biochar from mill residue produces AC with a higher BET surface area than biochar from forest residues. This result is consistent with studies relating high ash content to lower activation levels [51]. Though we did not activate BSI biochars using the industrial rotary calciner, in laboratory activation BSI biochars were activated to a higher level than TEA biochars, as evaluated by iodine adsorption (Figure 5). This result is expected based on the temperature of pyrolysis [52]. Both biochar products could be used as a precursor for the production of AC. Though it is difficult to compete with the economic efficiency and consistency of fossil coal as an AC precursor, biochar is from renewable resources, which may be an advantage in some markets for differentiated carbon products. Further, because woody biomass is available as a byproduct of forest management and timber production in many parts of the country and pyrolysis or gasification technology performs well at distributed scales, $\mathrm{AC}$ can be produced from biochar in a more distributed supply chain than characterizes AC from fossil coal. Distributed production might provide advantages in transportation efficiency to some individual AC users and local markets.

Activated carbon is only one potential use and market for biochar. The range of potential market-based uses of biochar, from fuel to soil amendment to AC, can enhance product and market diversification available to producers. This offers the possibility of increasing the portfolio of value-added products that can be produced from what are now waste byproducts of solid wood products manufacturing and forest management. 


\section{Conclusions}

Distributed thermochemical biomass conversion systems have the potential to meet a number of different operational needs associated with wood products manufacturing, including waste disposal, heat, power, and the production of marketable value-added products from woody biomass. The extent to which this potential can be achieved hinges on the qualities of the products these systems produce, potential uses for those products, and the financial viability of system integration compared to alternatives. In this study, we evaluated the outputs of two conversion systems used to process mill and forest residues and determined that the gas and biochar produced by these systems could be used to produce heat, electricity and a range of marketable products, but many questions remain.

Both of the systems examined in this paper are the subject of ongoing research. The authors and their colleagues are currently developing detailed financial models for system deployment in the forest sector based on experimental production and operations studies. Economic input-output models are being used to evaluate the potential economic benefits of co-locating these technologies with forest industry facilities in the western United States. The authors are also working to characterize gas, emissions and biochars from a wide range of woody feedstocks processed with these technologies. In particular, the variability of product quality, gas flow, and yield is being quantified in commercial settings over operational periods of days and weeks rather than hours. Additional research on the use of biochars in the production of AC is focused on chemical activation, and preliminary results using a proprietary activation process indicate that using a combination of steam and chemical activation can yield higher BET surface area AC from biochar produced by these systems than using steam activation alone.

The team is also collaborating on several lines of research to address the environmental impacts of pyrolysis conversion of woody biomass. BSI biochar has been incorporated into a number of field-based experimental studies to evaluate its effects on soil quality, soil function, and site productivity, with an emphasis on biochar application to forest soils. Broader environmental impacts are being evaluated using LCA of the TEA system and emissions analysis for both systems based on samples of gaseous and particulate matter emissions taken during testing and production runs. On the manufacturing side, both TEA and BSI are working to incorporate technical advances in producer gas utilization, feedstock drying, and biochar cooling into their systems, and have already moved beyond the prototypes examined in this study. New knowledge about the technical, logistical, economic, and environmental aspects of these and similar systems will be critical for guiding informed business and policy decisions associated with biomass conversion technologies.

\section{Acknowledgments}

The authors would like to thank our research partners, Tricon Timber, LLC; Biochar Solutions, Inc.; and Tucker Engineering Associates, especially Charlie Sells, Johan Levine and Richard Tucker. Emily Lincoln, Joanne Tirocke, Wilfredo Perez, and other personnel at the Rocky Mountain Research Station worked meticulously to analyze dozens of samples in the laboratories of Wei Min Hao, Deborah Page-Dumroese, and Jim Reardon. We would also like to acknowledge the work and guidance of Colleen Rostad and David Rutherford of the USGS, as well as the assistance of Chuck 
Rhoades and Kelly Elder in feedstock procurement. Additional thanks to Porous Materials, Inc.; Chem-Bac Laboratories, Inc.; Professional Analytical and Consulting Services; and Alstom Power. This research was supported by funding from the Rocky Mountain Research Station's Competitive Research Initiative and the USDA National Institute of Food and Agriculture's Biomass Research and Development Initiative.

\section{References}

1. U.S. Department of Energy. U.S. Billion-Ton Update: Biomass Supply for a Bioenergy and Bioproducts Industry; Perlack, R.D., Stokes, B.J., Eds.; ORNL/TM-2011/224; Oak Ridge National Laboratory: Oak Ridge, TN, USA, 2011; pp. 7-15.

2. Peterson, D.; Haase, S. Market Assessment of Biomass Gasification and Combustion Technology for Small- and Medium-Scale Applications; Technical Report NREL/TP-7A2-46190; National Renewable Energy Laboratory: Golden, CO, USA, 2009; pp. 1-32.

3. Turnbull, J. Use of biomass in electric power generation: The California experience. Biomass Bioenergy 1993, 4, 75-84.

4. Morgan, T. An Assessment of Forest-Based Woody Biomass Supply and Use in Montana; Forestry Assistance Bureau, Forestry Division, Montana Department of Natural Resources and Conservation: Missoula, MT, USA, 2009.

5. Jones, J.G.; Loeffler, D.; Calkin, D.; Chung, W. Forest residues for thermal energy compared with disposal by onsite burning: Emissions and energy return. Biomass Bioenergy 2010, 34, 737-746.

6. Korb, J.; Johnson, N.; Covington, W. Pile burning effects on soil biotic and chemical properties and plant establishment: Recommendations for amelioration. Restor. Ecol. 2004, 12, 52-62.

7. Fransham, P.; Badger, P. Use of mobile fast pyrolysis plants to densify biomass and reduce biomass handling cost—A preliminary assessment. Biomass Bioenergy 2006, 30, 321-325.

8. Garcia-Perez, M.; Lewis, T.; Kruger, C. Methods for Producing Biochar and Advanced Biofuels in Washington State, Part 1: Literature Review of Pyrolysis Reactors; Department of Biological Systems Engineering and the Center for Sustaining Agriculture and National Resources, Washington State University: Pullman, WA, USA, 2010; pp. 1-137.

9. El-Khattam, W.; Salama, M. Distributed generation technologies, definitions and benefits. Electric. Power Syst. Res. 2004, 71, 119-128.

10. Biochar Solutions, Incorporated (BSI). BSI Biochar Base Unit: Technical Specifications, Version 3.0.; Biochar Solutions, Incorporated: Carbondale, CO, USA, 2011.

11. PHG Energy. Industrial Grade Downdraft Gasification; PHG Energy: LaVergne, TN, USA, 2011. Available online: http://www.phgenergy.com (accessed on 7 January 2013).

12. Mohan, D.; Pittman, C., Jr.; Steele, P. Pyrolysis of wood/biomass for bio-oil: A critical review. Energy Fuels 2006, 20, 848-889.

13. Kumar, A.; Jones, D.; Hanna, M. Thermochemical biomass gasification: A review of the current status of the technology. Energies 2009, 2, 556-581.

14. Van der Stelt, M.; Gerhauser, H.; Kiel, J.; Ptasinski, K. Biomass upgrading by torrefaction for the production of biofuels: A review. Biomass Bioenergy 2011, 35, 3748-3762. 
15. Uslu, A.; Faaij, A.; Bergman, P. Pre-treatment technologies, and their effect on international bioenergy supply chain logistics. Techno-economic evaluation of torrefaction, fast pyrolysis and pelletisation. Energy 2008, 33, 1206-1223.

16. Prins, M.; Ptasinski, K.; Janssen F. Torrefaction of wood Part 2. Analysis of products. J. Anal. Appl. Pyrolysis 2006, 77, 35-40.

17. Rath, J.; Staudinger, G. Cracking reactions of tar from pyrolysis of spruce wood. Fuel 2001, 80, 1379-1389.

18. Hamelinck, C.; Faaij, A. Production of Methanol from Biomass. In Alcoholic Fuels; Miller, S., Ed.; Taylor and Francis Group: New York, NY, USA, 2006; pp. 7-50.

19. Tijmensen, M.; Faaij, A.; Hamelinck, C.; van Hardeveld, M. Exploration of the possibilities for production of Fischer Tropsch liquids and power via biomass gasification. Biomass Bioenergy 2002, 23, 129-152.

20. Jenkins, B.; Baxter, L.; Miles, T., Jr.; Miles, T. Combustion properties of biomass. Fuel Proc. Technol. 1998, 54, 17-46.

21. Biochar Solutions, Incorporated (BSI). Biochar Solutions: Overview; Biochar Solutions, Incorporated: Carbondale, CO, USA, 2011. Available online: http://www.biocharsolutions.com/ overview.html (accessed on 7 January 2013).

22. Bergman, R. Drying and Control of Moisture Content and Dimensional Changes. In Wood Handbook-Wood as an Engineering Material; General Technical Report FPL-GTR-113; USDA Forest Service, Forest Products Laboratory: Madison, WI, USA, 2010.

23. Nelson, D.; Sommers, L. Total Carbon, Organic Carbon, and Organic Matter. In Methods of Soil Analysis, Part 3-Chemical Methods; Soil Science Society of America, American Society of Agronomy: Madison, WI, USA, 1996; pp. 961-1069.

24. American Society for Testing and Materials (ASTM). ASTM D4607-94 (2011) Standard Test Method for Determination of Iodine Number of Activated Carbon; ASTM International: West Conshohocken, PA, USA, 2011.

25. Downie, A.; Crosky, A.; Munroe, P. Physical Properties of Biochar. In Biochar for Environmental Management Science and Technology; Lehmann, J., Joseph, S., Eds.; Earthscan: London, UK, 2006; pp. 13-32.

26. Elder, T.; Groom, W. Pilot-scale gasification of woody biomass. Biomass Bioenergy 2011, 35, 3522-3528.

27. Son, Y.; Yoon, S.; Kim, Y.; Lee, J. Gasification and power generation characteristics of woody biomass utilizing a downdraft gasifier. Biomass Bioenergy 2011, 35, 4215-4220.

28. Jenkins, B. Chapter 3.2.2: Pyrolysis Gas. In Handbook of Agricultural Engineering Volume V: Energy and Biomass Engineering; Kitani, O., Ed.; American Society of Agricultural Engineers: St. Joseph, MI, USA, 1999.

29. KiOR. KiOR Production Facilities. KiOR, Inc.: Columbus, MS, USA, 2011. Available online: http://www.kior.com/content/?s=6\&s $2=56 \& p=56 \& \mathrm{t}=$ Production-Facilities/ (accessed on 7 January 2013).

30. Bergman, P.; Boersma, A.; Kiel, J.; Zwart, R. Development of Torrefaction for Biomass Co-Firing in Existing Coal-Fired Power Stations; BIOCOAL Concept Version, ECN Report; Energy Research Center of the Netherlands: Petten, The Netherlands, 2005. 
31. Abdullah, H.; Wu, H. Biochar as a fuel: 1. Properties and grindability of biochars produced from the pyrolysis of mallee wood under slow-heating conditions. Energy Fuels 2009, 23, 4174-4181.

32. Antal, M., Jr.; Croiset, E.; Dai, X.; DeAlmeida, C.; Shu-Lai Mok, W.; Norberg, N. High-yield biomass charcoal. Energy Fuels 1996, 10, 652-658.

33. Ertas, M.; Alma, M. Pyrolysis of laurel (Laurusnobilis L.) extraction residues in a fixed-bed reactor: Characterization of bio-oil and bio-char. J. Anal. Appl. Pyrolysis 2010, 88, 22-29.

34. Sukiran, M.; Kheang, L.; Bakar, N.; May, C. Production and characterization of bio-char from the pyrolysis of empty fruit bunches. Am. J. Appl. Sci. 2011, 8, 984-988.

35. Federal Energy Management Program (FEMP). Biomass Cofiring in Coal-Fired Boilers; Federal Technology Alert DOE/EE-0288; U.S. Department of Energy, Energy Efficiency and Renewable Energy: Washington, DC, USA, 2004.

36. Tillman, D. Biomass cofiring: The technology, the experience, the combustion consequences. Biomass Bioenergy 2000, 19, 365-384.

37. Demirbas, A. Sustainable cofiring of biomass with coal. Energy Convers. Manag. 2003, 44, 1465-1479.

38. Lehmann, J. Bio-energy in the black. Front. Ecol. Environ. 2007, 5, 381-387.

39. Laird, D.A. The charcoal vision: A win-win-win scenario for simultaneously producing bioenergy, permanently sequestering carbon, while improving soil and water quality. Agron. J. 2008, 100, 178-181.

40. Mbagwu, J.; Piccolo, A. Effects of Humic Substances from Oxidized Coal on Soil Chemical Properties and Maize Yield. In The Role of Humic Substances in Ecosystems and in Environmental Protection; Drozd, J., Gonet, S.S., Senesi, N., Weber, J., Eds.; Polish Society of Humic Substances: Wroclaw, Poland, 1997; pp. 921-925.

41. Brodowski, S.; John, B.; Flessa, H.; Amelung, W. Aggregate-occluded black carbon in soil. Eur. J. Soil Sci. 2006, 57, 539-546.

42. Lehmann, J. Biochar for Environmental Management; Earthscan: London, UK, 2009.

43. McElligott, K. Biochar Amendments to Forest Soils: Effects on Soil Properties and Tree Growth. MSc Thesis, University of Idaho: Moscow, ID, USA, 2011.

44. Meurisse, R.T. Propoerties of Anidsols Important for Forestry. 1985. In Proceedings, Western Hemlock Management Conference; Atkinson, W.A., Zozoski, R.T., Eds.; University of Washington: Seattle, WA, USA, 1976.

45. McElligott, K.; Page-Dumroese, D.; Coleman, M. Bioenergy Production Systems and Biochar Application in Forests: Potential for Renewable Energy, Soil Enhancement, and Carbon Sequestration; Research Note RMRS-RN-26; Rocky Mountain Research Station: Moscow, ID, USA, 2011.

46. Pollard, S.; Fowler, G.; Sollars, C. Low-cost adsorbents for waste and wastewater treatment: A review. Sci. Total Environ. 1992, 116, 31-52.

47. Teng, $\mathrm{H}$.; Lin, H. Activated carbon production from low ash subbituminous coal with $\mathrm{CO}_{2}$ activation. Mater. Interfaces Electrochem. Phenom. 1998, 44, 1170-1177.

48. Teng, H.; Yeh, T.; Hsu, L. Preparation of activated carbon from bituminous coal with phosphoric acid activation. Carbon 1998, 36, 1387-1395. 
49. Kobya, M.; Demirbas, E.; Senturk, E.; Ince, M. Adsorption of heavy metal ions from aqueous solutions by activated carbon prepared from apricot stone. Bioresour. Technol. 2005, 96, $1518-1521$.

50. Benaddi, H.; Bandosz, T.; Jagiello, J.; Schwarz, J.; Rouzaud, J.; Legras, D.; Beguin, F. Surface functionality and porosity of activated carbons obtained from chemical activation of wood. Carbon 2000, 38, 669-674.

51. Azargohar, R.; Dalai, A. Biochar as a precursor of activated carbon. Appl. Biochem. Biotechnol. 2006, 131, 762-773.

52. Evans, M.; Halliop, E.; MacDonald, J. The production of chemically-activated carbon. Carbon 1999, 37, 269-274.

(C) 2013 by the authors; licensee MDPI, Basel, Switzerland. This article is an open access article distributed under the terms and conditions of the Creative Commons Attribution license (http://creativecommons.org/licenses/by/3.0/). 